\title{
Evaluation of antimicrobial activity of five Vincetoxicum taxa growing in Turkey
}

\author{
Sevda GÜZEL ${ }^{*}$, Mahmut ÜLGER 2, Gönül ASLAN 3, Gamze KÖKDİL ${ }^{1}$ \\ 1 Department of Pharmacognosy, Faculty of Pharmacy, Mersin University, 33169, Mersin, Turkey. \\ 2 Department of Pharmaceutical Microbiology, Faculty of Pharmacy, Mersin University, 33169, Mersin, Turkey. \\ 3 Department of Medical Microbiology, Faculty of Medicine, Mersin University, 33169, Mersin, Turkey. \\ * Corresponding Author. E-mail: guzelsevda@mersin.edu.tr (S.G.); Tel. +90-553-126 3692 ; ORCID No: 0000-0002- \\ 6642-5824.
}

Received: 16 February 2018 / Revised: 28 April 2018 / Accepted: 04 May 2018

\begin{abstract}
The antibacterial, antifungal and antimycobacterial effects of ethanolic extracts obtained from aerial parts and roots of five Vincetoxicum taxa (V. canescens subsp. canescens, V. canescens subsp. pedunculata, V. parviflorum, V. fuscatum subsp. fuscatum and $V$. fuscatum subsp. boissieri) were tested against two Gram $(+)$ bacterial strains (Staphylococcus aureus and Bacillus subtilis), three Gram (-) bacterial strains (Escherichia coli, Acinetobacter baumannii and Aeromonas hydrophila), three fungal strains (Candida glabrata, Candida parapsilosis and Candida tropicalis) and Mycobacterium tuberculosis by using the broth dilution method. Ethambutol, Isoniazid, Ampicillin and Fluconazole were used as reference antimicrobial agents. All tested extracts showed significant antibacterial activity against A. baumannii with MIC values ranging from 31.25 to $62.5 \mu \mathrm{g} / \mathrm{ml}$ when compared to reference drug Ampicillin with $125 \mu \mathrm{g} / \mathrm{ml} \mathrm{MIC}$ value. Moreover, the extracts obtained from aerial parts of $V$. fuscatum subsp. boissieri and roots of $V$. canescens subsp. pedunculata were found the most effective extracts against $A$. baumannii with $31.25 \mu \mathrm{g} / \mathrm{ml}$ MIC value.
\end{abstract}

KEYWORDS: Vincetoxicum; antimicrobial activity; plant extract; broth microdilution method; Acinetobacter baumannii.

\section{INTRODUCTION}

Infectious diseases including nosocomial infections caused by various microorganisms have become a major health problem worldwide due to emerging multi-drug resistant strains. Antimicrobial resistant strains lead to serious infections like urinary tract, pneumonia and bloodstream infections [1,2]. New antimicrobial agents with novel mechanisms of action are needed to fight effectively against infectious diseases [1]. This unmet need resulted from a variety of factors such as manufacturing synthetic agents with high costs, various adverse effects and ability to develop resistance to all classes of antimicrobial agents used against them [1, 3, 4]. Nowadays, one of the most popular way of exploring new antimicrobial agents with low cost is to use medicinal plants as a source $[4,5]$. More than 20.000 plant species with medicinal properties are listed by The World Health Organization (WHO) for treating various illnesses like pneumonia, diarrhea, ulcers, colds and bronchitis [6]. Furthermore, according to literature, approximately $40 \%$ of antimicrobial agents are naturally sourced [5].

The genus Vincetoxicum N.M. Wolf which is one of the members of Apocynaceae; subfamily Asclepiadoideae [7, 8] comprises nearly 100 species which are distributed throughout Asia, Europe, Japan [9] and North America [10]. Leaves, rhizome and dry seeds of Vincetoxicum species have various usages in folk medicine due to medicinal purposes [11]. V. hirundinaria Medik, V. nigrum (L.) Moench and V. stocksii Ali \& Khatoon have been traditionally used in different medicinal systems like European and Chinese for the treatment of neurosis, malaria, scrofula, injuries, rupture, fever, scabies, wounds $[7,11,12]$ and as expectorant, diuretic, emetic [13, 14], antileishmanial [12], antitumoral [7, 15], laxative and diaphoretic agents [7]. In Pakistan, poultice of $V$. stocksii has been externally used for the treatment of injuries, wounds and cancers [12]. In the field of veterinary medicine, roots of $V$. hirundinaria have been used to treat dropsy and some other illnesses [7]. The plant is known as "dompte-venin" in France and used as emetic and expectorant [16]. Infusion and decoction of the roots and whole plant are used as antidote for poisons in Italy [17], while in Turkey the plant is known as "Kırlangıç kuyruğu or Panzehir otu" and emetic properties of roots were reported [18]. In

How to cite this article: Güzel S, Ülger M, Aslan G, Kökdil G. Evaluation of antimicrobial activity of five Vincetoxicum taxa growing in Turkey. Marmara Pharm J. 2018; 22 (3): 365-373. 
East Anatolia, V. canescens (Willd.) Decne. subsp. canescens is locally known as "Zilasur or Zehir otu" [19, 20], and crushed parts of the plant have been externally used for the treatment of scabies [19] and fungal infections $[19,20]$.

Antifungal and antibacterial activities of $V$. rossicum (Kleo.) Barb. and V. nigrum [21, 22]; antifungal, antibacterial [12,23], antileishmanial and antimalarial activities of $V$. stocksii [12] and antioxidant activity of $V$. lutea L. [11] have been determined. Furthermore, cytotoxic [24, 25], antifeedant and growth inhibition [26-28] effects of the genus were also reported.

Phytochemical investigations revealed the presence of triterpenoids [13, 15], phenanthroindolizidine alkaloids [21, 22, 25], steroids [15] and sugars [27, 29] in whole parts of the Vincetoxicum species. Moreover, acetophenone, volatile compounds [13], starch [27] and saponins [27, 30] were detected from the roots, and alkanols [15] and tannins [28] were detected from the aerial parts. As another secondary metabolites flavonoids $[14,23]$ and steroidal glycosides [14, 15] were found in Vincetoxicum species.

The genus Vincetoxicum is one of the largest genera of the subfamily Asclepiadoideae in Turkey and represented by 10 taxa that three of them (Vincetoxicum canescens (Willd.) Decne. subsp. pedunculata Browicz, Vincetoxicum parviflorum Decne. and Vincetoxicum fuscatum (Hornem.) Reichb. subsp. boissieri (Kusn) Browicz) are endemic to Turkey [30,31]. Vincetoxicum species growing wild in Turkey were firstly investigated in our previous studies for their phytoconstituents [28], antifeedant activities against Spodoptera littoralis and Leptinotarsa decemlineata [27, 28] and antifungal activity against Aspergillus fumigatus [32]. There is no investigation on antibacterial activities of Turkish Vincetoxicum species in the literature. Therefore, the aim of the present study was to evaluate antibacterial, antifungal and antimycobacterial effects of ethanolic extracts obtained from aerial parts and roots of five Vincetoxicum taxa ( $V$. canescens subsp. canescens, $V$. canescens subsp. pedunculata, V. parviflorum, V. fuscatum subsp. fuscatum (Hornem.) Reichb. and V. fuscatum subsp. boissieri) against two Gram (+) bacterial strains [Staphylococcus aureus (ATCC 25925) and Bacillus subtilis (ATCC 6633)], three Gram (-) bacterial strains [Escherichia coli (ATCC 25923), Acinetobacter baumannii (ATCC 02026) and Aeromonas hydrophila (ATCC 95080)] and Mycobacterium tuberculosis H37Rv, and three fungal strains [Candida glabrata (ATCC 90030), Candida parapsilosis (ATCC 22019) and Candida tropicalis (ATCC 750)].

\section{RESULTS AND DISCUSSION}

The antibacterial, antifungal and antimycobacterial activities of ethanolic extracts obtained from different parts of $V$. canescens subsp. canescens, $V$. canescens subsp. pedunculata, $V$. parviflorum, $V$. fuscatum subsp. fuscatum and $V$. fuscatum subsp. boissieri growing in Turkey were tested against Gram (+) (S. aureus, $B$. subtilis), Gram (-) bacterial strains (E. coli, A. baumannii, A. hydrophila), fungal strains (C. glabrata, C. parapsilosis, C. tropicalis) and M. tuberculosis. The percentage yields of ethanolic extracts with further details of the studied plants were given in Table 1. The antibacterial [33] and antifungal [34-36] activities were performed using the broth dilution method assay and antimycobacterial activity [37] was performed using the REMA plate method assay. Ampicillin, Ethambutol, Isoniazid and Fluconazole were used as reference antimicrobial agents. The antibacterial and antifungal activity results were given in Tables 2 and 3, respectively.

The antibacterial activity results revealed that the ethanolic extracts obtained from aerial parts and roots of studied plants exhibited antibacterial activity with different MIC values against all tested bacterial strains when compared to reference antibacterial agents (Ampicillin, Ethambutol, Isoniazid). All tested extracts showed significant antibacterial activity against A. baumannii ranging from 31.25 to $62.5 \mu \mathrm{g} / \mathrm{ml}$ MIC values when compared to reference drug Ampicillin with $125 \mu \mathrm{g} / \mathrm{ml}$ MIC value. Especially, the extracts of roots of $V$. canescens subsp. pedunculata and aerial parts of $V$. fuscatum subsp. boissieri were found the most effective against A. baumannii with $31.25 \mu \mathrm{g} / \mathrm{ml}$ MIC value (Table 2).

Against B. subtilis, the ethanolic extracts obtained from aerial parts of $V$. parviflorum and roots of $V$. canescens subsp. canescens indicated significant antibacterial efficiency with $31.25 \mu \mathrm{g} / \mathrm{ml}$ MIC value while the other tested extracts showed lower antibacterial efficiency with $62.5 \mu \mathrm{g} / \mathrm{ml} \mathrm{MIC} \mathrm{value.} \mathrm{Comparison} \mathrm{of} \mathrm{MIC}$ values of tested extracts and reference drug demonstrated that tested extracts were not found effective as reference drug Ampicillin ( $0.9 \mu \mathrm{g} / \mathrm{ml}$ MIC value) (Table 2).

The all studied extracts showed growth inhibitory effect against $M$. tuberculosis with $31.25 \mu \mathrm{g} / \mathrm{ml}$ MIC value except root extracts of $V$. fuscatum subsp. fuscatum with $62.5 \mu \mathrm{g} / \mathrm{ml}$ MIC value. However, the effectiveness of the all extracts was found lower than reference antimycobacterial agents Isoniazid and Ethambutol (0.97 and $1.95 \mu \mathrm{g} / \mathrm{ml}$ MIC values, respectively) (Table 2). 
The results of antifungal activity studies demonstrated that the all studied plants displayed growth inhibition effects on tested fungal strains with different MIC values ranged from 15.62 to $62.5 \mu \mathrm{g} / \mathrm{ml}$. When compared the efficiency of the all tested extracts on C. glabrata, the ethanolic extract obtained from aerial parts of $V$. fuscatum subsp. boissieri found the most effective with $31.25 \mu \mathrm{g} / \mathrm{ml}$ MIC value. Also root extracts of $V$. parviflorum and $V$. fuscatum subsp. fuscatum showed the highest efficiency against $C$. tropicalis with the same MIC value $(31.25 \mu \mathrm{g} / \mathrm{ml})$. The root extracts of all studied plants exhibited significant antifungal activity on $C$. parapsilosis with $15.62 \mu \mathrm{g} / \mathrm{ml}$ MIC value, except root extract of $V$. canescens subsp. pedunculata $(62.5 \mu \mathrm{g} / \mathrm{ml} \mathrm{MIC}$ value). The Fluconazole had different MIC values against C. glabrata, C. parapsilosis and C. tropicalis with 3.90, 15.62 and $3.90 \mu \mathrm{g} / \mathrm{ml}$, respectively. Comparison of MIC values of extracts and reference antifungal agent Fluconazole indicated that the plant extracts exhibited lower efficiency than reference agent (Table 3).

Some of the secondary metabolites including flavonoids, phenolic acids, tannins, saponins, alkaloids, terpenoids, essential oils [38, 39], polysaccharides and sterols [40] were reported to have antimicrobial properties. Choosing the extraction solvent is important to get active component extract. Ethanol was a suitable solvent for phenolics, alkaloids, sterols, terpenoids [39] and broad range of polar constituents [41]. So in the present study ethanol was chosen as an extraction solvent.

In our previous studies, phytochemical screening of these Vincetoxicum taxa indicated that the aerial parts of the whole plants contain alkaloids, flavonoids, sugars and cardiactive glycosides, and also three of them ( $V$. fuscatum subsp. boissieri, $V$. fuscatum subsp. fuscatum and V. parviflorum) contain tannins [28], and the roots of the whole plants contain steroidal glycosides, starch and sugars, and one of them ( $V$. fuscatum subsp. boissieri) contains saponins [27]. Furthermore, presence of phenanthroindolizidine alkaloids in aerial parts of the tested plants were demonstrated by LC/MS/MS analysis [28].

Antimicrobial activity of different Vincetoxicum species were examined in a few study [21, 23, 32, 42]. Bazzaz and Haririzadeh (2003) tested antimicrobial activity of methanol extract obtained from total parts of Vincetoxicum pumilum Decne. against seven bacterial strains including B. subtilis, S. aureus, E. coli, and a fungus Candida albicans by using cylinder plate assay method. They found that the plant extract showed significant antifungal activity against $C$. albicans while there were no effects observed against tested bacteria [42]. Zaidi and Crow (2005) studied various fractions (ethyl acetate, hexane, butanol, chloroform and water) of methanol extract obtained from $V$. stocksii for their antimicrobial activities against 12 fungal strains including C. albicans and 12 bacterial strains including B. subtilis, E. coli and S. aureus by agar well diffusion and disk diffusion assays. The study results indicated that the tested plant exhibited significant antimicrobial activity against $B$. subtilis and $C$. albicans and moderate activity against $E$. coli, while there were no activity observed against $S$. aureus at $200 \mu \mathrm{g} / \mathrm{ml}$ concentration [23]. Mogg et al. (2008) evaluated antimicrobial activity of ethanolic extracts obtained from roots, fresh leaves and mature fruits of $V$. rossicum against some fungi and bacteria. They found that the plant had antimicrobial activity, and the root extract also showed greater activity than the leaves [21]. In our previous study, four extracts of increasing polarity $\left(\mathrm{CH}_{2} \mathrm{Cl}_{2}, \mathrm{CH}_{2} \mathrm{Cl}_{2}: \mathrm{MeOH}(1: 1), \mathrm{MeOH}\right.$ and total $\mathrm{EtOH}$ ) obtained from root and aerial part of each of the five Vincetoxicum taxa evaluated for their antifungal activity against $A$. fumigatus at $1 \mathrm{mg} / \mathrm{ml}$ concentration by using agar dilution method. In tested forty extracts, the $\mathrm{CH}_{2} \mathrm{Cl}_{2}$ extracts of aerial part and root of $V$. parviflorum and root of $V$. canescens subsp. canescens were exhibited the highest inhibitory effect against $A$. fumigatus with inhibition value of $45.86 \%$ [32]. In the present study the root extracts of all studied plants exhibited significant antifungal activity against $C$. parapsilosis.

Generally, Gram (-) bacterial strains are more resistant than Gram (+) bacterial strains [40, 43], the cell wall of the Gram (-) bacteria are more complex than the Gram (+) bacteria. The outer membranes of Gram (-) and Gram $(+)$ bacteria are arranged differently so the differences are affected penetration of macromolecules during the treatment [44]. Moreover, Gram (-) bacteria are more resistant against natural components than Gram (+) bacteria. The hydrophilic cell wall structure of Gram (-) bacteria contains lipopolysaccharide and this structure inhibits the penetration of hydrophobic oils, steroids and extracts, and accumulation of them in the target cell membrane. This information confirmed why Gram (+) bacteria indicated greater sensitivity against natural products than Gram (-) bacteria [40]. According to the literature this is the first study on antibacterial effect of Vincetoxicum genus against Gram (-) nosocomial pathogen A. baumannii which becomes a severe healthcare problem worldwide due to its ability to gain resistance to all classes of antimicrobial compounds used against it [45]. This microorganism takes clinical attention in intensive care units (ICU) and also responsible from broad range of infections such as bacteremia, urinary tract, meningitis, bloodstream, ventilator associated pneumonia and infections of surgical wound [2]. In the present study, all tested plants showed stronger antibacterial activity against $A$. baumannii when compared to reference drug Ampicillin. The extract of the root of $V$. canescens subsp. pedunculata and aerial part of $V$. fuscatum subsp. boissieri were found 
the most effective. The findings indicated that the tested plants can be a promising source of antimicrobial agents in the treatment of infections caused by A. baumannii.

\section{CONCLUSION}

The activity of five Vincetoxicum taxa on tested microorganisms was indicated that further examination with detailed studies is needed to confirm the effect of them to use these plants as a source of antimicrobial agents for the treatment of infectious disease. Especially, examination of two Vincetoxicum taxa $(V$. canescens subsp. pedunculata and $V$. fuscatum subsp. boissieri) which exhibited the highest effectiveness against $A$. baumannii is required. In a conclusion, further investigations on various microorganisms, animal studies, mode of action mechanisms, toxicity tests, comparison of the efficiency of extracts and active components are another important studies should be done in the future.

\section{MATERIALS AND METHODS}

\subsection{Chemicals}

Isoniazid (Sigma, I3377), Fluconazole (Sigma, F8929), Ethambutol (Sigma, E4630), RPMI 1640 Medium (Sigma, R6504), 3-(N-morpholino)-propanesulfonic acid (MOPS, Sigma, M1254), Resazurin sodium salt powder (Sigma R7017), Ethanol (EtOH) and Dimethyl sulfoxide (DMSO) were purchased from Sigma-Aldrich (St. Louis, MO, USA). Middlebrook 7H9 broth and casitone, glycerol and oleic acid-albumin-dextrose-catalase were purchased from Becton Dickinson (Sparks, MD, USA). The all solutions were prepared with distilled water and for the experiments freshly prepared solutions were used.

\subsection{Microbial strains}

Bacterial strains [Staphylococcus aureus (ATCC 25925), Escherichia coli (ATCC 25923), Bacillus subtilis (ATCC 6633), Acinetobacter baumannii (ATCC 02026) and Aeromonas hydrophila (ATCC 95080)], fungal strains [Candida glabrata (ATCC 90030), Candida parapsilosis (ATCC 22019) and Candida tropicalis (ATCC 750)] and Mycobacterium tuberculosis H37Rv were obtained from the Refik Saydam Hifzıssihha Institute, Ankara, Turkey.

\subsection{Plant materials}

Plant materials were collected from their natural habitats in different regions of Turkey and identified by Dr. Sevda Güzel and confirmed by Dr. Ahmet İlçim, Department of Biology, Faculty of Arts and Science, Mustafa Kemal University (Antakya, Turkey). The dried voucher specimens were stored in the herbarium of the Mustafa Kemal University (Further details were given in Table 1).

\subsection{Extraction procedure}

The powdered air dried aerial parts and roots were extracted three times with $96 \%$ ethanol $(500 \mathrm{ml}$ of solvent per $100 \mathrm{~g}$ of plant material), sonicated for $30 \mathrm{~min}$. and at room temperature left overnight with shaking [21]. After filtrated with Whatman No.1 filter paper, the solvents were evaporated at $35-40^{\circ} \mathrm{C}$ under reduced pressure by using vacuum evaporator (Heidolph-Rotar TLR 1000) and the extracts were kept in dark at $4^{\circ} \mathrm{C}$.

\subsection{Antimicrobial assays}

The antimicrobial activities of ethanolic extracts obtained from five Vincetoxicum taxa were evaluated by using two different methods. The broth dilution method assay was used for antibacterial [33] and antifungal [34-36] activities and the resazurin microtitre assay (REMA) plate method was used for antimycobacterial activity [37].

\subsubsection{Antibacterial assay}

Antibacterial activity of the extracts was tested against two Gram (+) bacterial strains: S. aureus (ATCC 25925) and B. subtilis (ATCC 6633); three Gram (-) bacterial strains: E. coli (ATCC 25923), A. baumannii (ATCC 02026) and A. hydrophila (ATCC 95080). Ampicillin, which is a semi-synthetic penicillin with broad spectrum, was chosen as a reference antibacterial agent. Antibacterial assay was performed using a literature method [33]. Stock solutions of the extracts $(2000 \mu \mathrm{g} / \mathrm{ml})$ were prepared by dissolving $2 \mathrm{mg}$ of the extract in $1 \mathrm{ml}$ of DMSO. The $1 \mathrm{ml}$ of Mueller-Hinton broth was added to the all sterilized tubes, then stock solution of the extract was added to the first tube which contain Mueller - Hinton broth. After that, $1 \mathrm{ml}$ solution was 

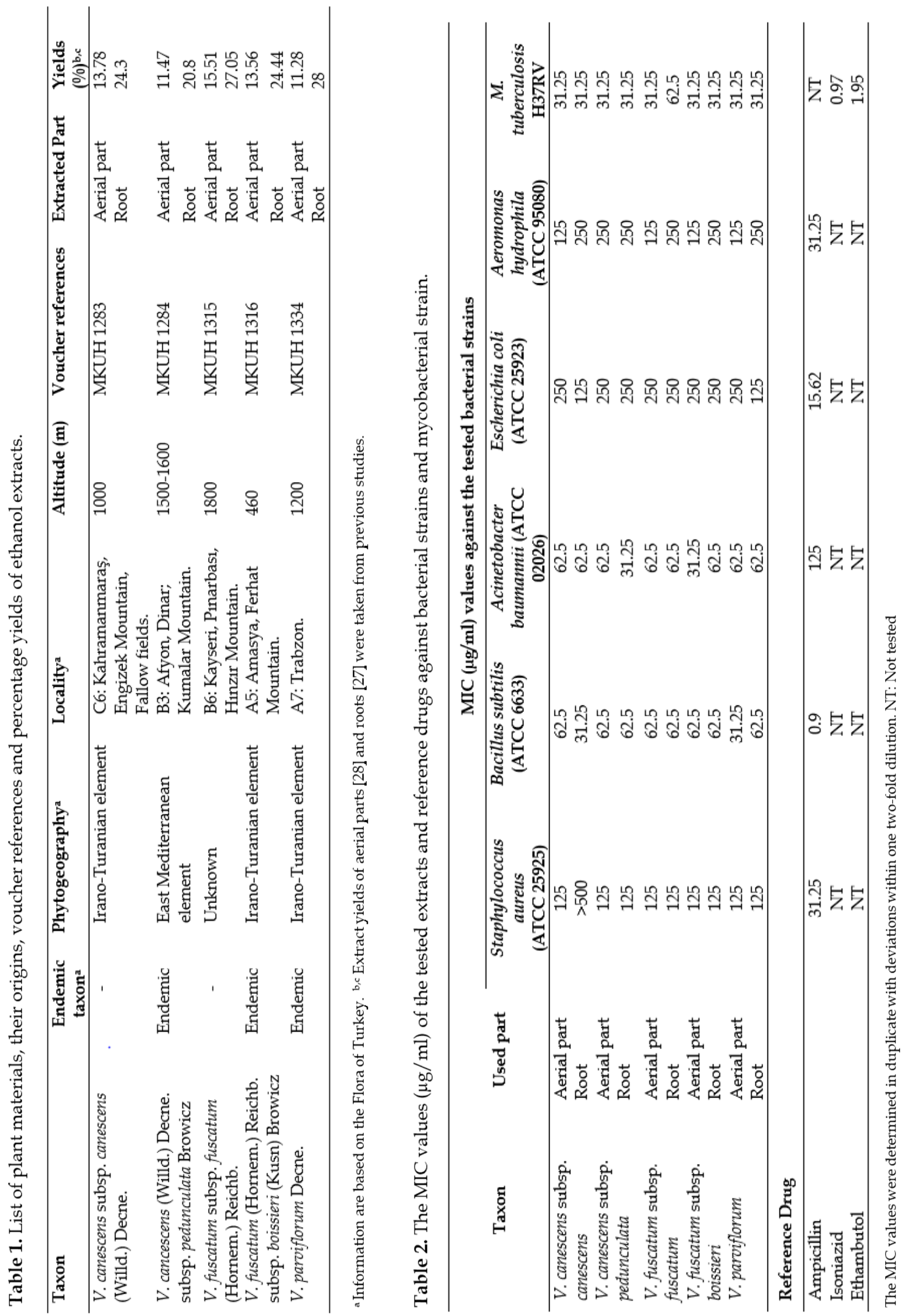
Table 3. The MIC values of the tested extracts and reference drug against fungal strains $(\mu \mathrm{g} / \mathrm{ml})$.

\begin{tabular}{|c|c|c|c|c|}
\hline \multirow{2}{*}{ Taxon } & \multirow{2}{*}{ Used part } & \multicolumn{3}{|c|}{ MIC $(\mu \mathrm{g} / \mathrm{ml})$ values* against the tested fungal strains } \\
\hline & & $\begin{array}{c}\text { Candida glabrata } \\
\text { (ATCC 90030) }\end{array}$ & $\begin{array}{c}\begin{array}{c}\text { Candida tropicalis } \\
\text { (ATCC 750) }\end{array} \\
\end{array}$ & $\begin{array}{c}\text { Candida parapsilosis } \\
\text { (ATCC 22019) }\end{array}$ \\
\hline \multirow[t]{2}{*}{ V. canescens subsp. canescens } & Aerial part & 62.5 & 62.5 & 62.5 \\
\hline & Root & 62.5 & 62.5 & 15.62 \\
\hline \multirow[t]{2}{*}{$V$. canescens subsp. pedunculata } & Aerial part & 62.5 & 62.5 & 62.5 \\
\hline & Root & 62.5 & 62.5 & 62.5 \\
\hline \multirow{2}{*}{$V$. fuscatum subsp. fuscatum } & Aerial part & 62.5 & 62.5 & 62.5 \\
\hline & Root & 62.5 & 31.25 & 15.62 \\
\hline \multirow[t]{2}{*}{ V. fuscatum subsp. boissieri } & Aerial part & 31.25 & 62.5 & 62.5 \\
\hline & Root & 62.5 & 62.5 & 15.62 \\
\hline \multirow[t]{2}{*}{$V$. parviflorum } & Aerial part & 62.5 & 62.5 & 62.5 \\
\hline & Root & 62.5 & 31.25 & 15.62 \\
\hline \multicolumn{5}{|l|}{ Reference Drug } \\
\hline Fluconazole & & 3.90 & 15.62 & 3.90 \\
\hline
\end{tabular}

transferred from first tube to the subsequent tube, and this process was repeated sequentially for serial dilution. Thus, each tube contained $1 \mathrm{ml}$ of solution in serially descending concentrations $(1000,500,250,125$, 62.5, 31.25, 15.62, 7.8, 3.9 and $1.9 \mathrm{\mu g} / \mathrm{ml}$ ). This dilution series were also applied for Ampicillin [33]. Standard strains working suspensions were prepared in sterile tubes and turbidity adjusted to match McFarland standard No: 0.5 , then 1:20 dilution of each suspension was prepared by using distilled water. $10 \mu$ lof prepared bacterial suspension was added in each plate and bacterial concentration of each plate adjusted to $5 \times 10^{5}$ $\mathrm{CFU} / \mathrm{ml}[46]$. The microbial growth effects of tested solvent (DMSO) was also checked with a control test containing inoculated broth and DMSO was added at the same dilutions mentioned above. The results of control test indicated that the tested solvent had no growth effect on bacterial strains. The minimal inhibitory concentration (MIC) value of each extract was determined in duplicate tests.

\subsubsection{Antimycobacterial assay}

1. Culture medium: For the REMA plate method assay 7H9-S medium was prepared with Middlebrook $7 \mathrm{H} 9$ broth including $0.1 \%$ casitone, $0.5 \%$ glycerol and $10 \%$ oleic acid-albumin-dextrose-catalase.

2. Resazurin reagent: The resazurin sodium salt powder was used for preparing resazurin reagent. A working solution of resazurin reagent was made in distilled water at $0.01 \%(\mathrm{w} / \mathrm{v})$ concentration and filtered to sterilize by using $0.22 \mu \mathrm{m}$ membrane filter (Ministar, Sartorius Stedim Biotech $\mathrm{GmbH}$, Goettingen, Germany); the prepared solution was kept for up to 1 week at $4^{\circ} \mathrm{C}$.

3. The REMA plate method: This method was performed in duplicate according to the method mentioned at Nateche et al. [37] with minor changes. As the standard strain M. tuberculosis H37Rv and as reference antimycobacterial agents Ethambutol and Isoniazid were used. Stock solutions of the studied extracts and reference agents were prepared at $1000 \mu \mathrm{g} / \mathrm{ml}$ concentration in DMSO. $0.22 \mu \mathrm{m}$ membrane filters were used for filtration procedure of the prepared solutions. In a 96-well microtitre plate, two-fold dilution series of all solutions were made by using 7H9-S (100 $\mu \mathrm{l})$. The concentrations ranging from 0.12 to $250 \mu \mathrm{g} / \mathrm{ml}$ were tested. A sterility control without inoculum and a growth control containing no antibiotic were added in tested plate. H37Rv inoculum was made by resuspending a loopful of the Lowenstein-Jensen culture medium in a tube containing $5 \mathrm{ml}$ 7H9-S medium with several glass beads and the tube was mixed by vortex during 2 min then waited for $30 \mathrm{~min}$ to form sediment. The supernatant was passed to another sterile tube and the turbidity adjusted to match a McFarland standard No.1; this prepared suspension was diluted again in 7H9-S (1:20). All studied plates were inoculated with suspension $(100 \mu \mathrm{l})$ and put in plastic bags for sealing; then incubated at $37^{\circ} \mathrm{C}$. After incubating for 7 days, resazurin working solution $(30 \mu \mathrm{l})$ was put into each well and then at $37^{\circ} \mathrm{C}$ the each plate was incubated for $24 \mathrm{~h}$. The results were recorded visually. The resazurin color changes from blue to pink, indicates reducing of resazurin and this was revealed bacterial growth. For having a positive result, the color change exhibiting bacterial growth has to be comparable to that seen in the positive growth control. The MIC values were described as minimum solution concentrations which prevented a full color change of the resazurin from blue to pink. 


\subsubsection{Antifungal assay}

The antifungal activity of the each extract was studied against three fungal strains [C. glabrata (ATCC 90030), C. parapsilosis (ATCC 22019) and C. tropicalis (ATCC 750)] by using the microdilution broth method [35, 36] which was mentioned at the NCCLS standard document M27-A2 [34]. A synthetic triazole antifungal agent, Fluconazole was chosen as a reference drug. Antifungal assay was carried out in RPMI 1640 Medium which buffered to $\mathrm{pH} 7.0$ with $0.165 \mathrm{M} 3$-(N-morpholino)-propanesulfonic acid. The each standard strain's working suspension was prepared by a 1:100 dilution followed by a 1:20 dilution of the stock suspension with RPMI 1640 medium. Stock solutions of reference antifungal agent and each studied extract were made in DMSO at $1000 \mu \mathrm{g} / \mathrm{ml}$ concentration. For filtration of the prepared solutions $0.22 \mu \mathrm{m}$ membrane filter was used. Two-fold dilution series of reference antifungal agent and the solutions were prepared in a 96-well microtitre plate by using RPMI 1640 medium (100 $\mu \mathrm{l})$. The concentrations range from 0.12 to $250 \mu \mathrm{g} / \mathrm{ml}$ were tested. A sterility control without inoculum and a growth control containing no antibiotic were added in each plate. Also $100 \mu \mathrm{l}$ of the working inoculum suspension was put into each plate. The incubation of the plates was performed in ambient air for $48 \mathrm{~h}$ at $35^{\circ} \mathrm{C}$. The MIC value was minimum concentration of the each extract which inhibited growth of the organism was visually determined.

Acknowledgements: For authentication of the plant samples, the authors would like to add special thanks to the Dr. Ahmet İlçim (Department of Biology, Faculty of Arts and Science, Mustafa Kemal University (Antakya, Turkey).

Author contributions: Concept - S. G., G. K.; Design - S. G., G. K.; Supervision - S. G., G. K., M. Ü.; Resource - S. G., M. Ü., G. A., G. K.; Materials - S. G., M. Ü., G. A., G. K.; Data Collection and/or Processing - S. G., M. Ü., G. A., G. K.; Analysis and/or Interpretation - S. G., M. Ü., G. A., G. K.; Literature Search - S. G., M. Ü.; Writing - S. G., G. K., M. Ü.; Critical Reviews - S. G., M. Ü., G. A., G. K.

Conflict of interest statement: The authors declared no conflict of interest

\section{REFERENCES}

[1] Ngezahayo J, Ribeiro SO, Fontaine V, Hari L, Stévigny C, Duez P. In vitro study of five herbs used against microbial infections in Burundi. Phytother Res. 2017; 31(10): 1571-1578.

[2] Shamsizadeh Z, Nikaeen M, Esfahani BN, Mirhoseini SH, Hatamzadeh M, Hassanzadeh A. Detection of antibiotic resistant Acinetobacter baumannii in various hospital environments: potential sources for transmission of Acinetobacter infections. Environ Health Prev Med. 2017; 22(44): 1-7.

[3] Pașca C, Màrghitaş L, Dezmirean D, Bobiş O, Bonta V, Chirilà F, Matei I, Fiț N. Medicinal plants based products tested on pathogens isolated from Mastitis Milk. Molecules. 2017; 22(9): 1473-1489.

[4] Uma K, Xin H, Kumar BA. Antifungal effect of plant extract and essential oil. Chin J Integr Med. 2017; 23(3): $233-239$.

[5] Ayoub IM, El-Shazly M, Lu MC, Singab ANB. Antimicrobial and cytotoxic activities of the crude extracts of Dietes bicolor leaves, flowers and rhizomes. S Afr J Bot. 2014; 95: 97-101.

[6] Siddiqui W, Sharangi AB, Singh JP, Thakur PK, Ayala-Zavala JF, Singh A, Dhua RS. Antimicrobial properties of teas and their extracts in vitro. Crit Rev Food Sci Nutr. 2016; 56(9): 1428-1439.

[7] DiTommaso A, Lawlor FM, Darbyshire SJ. The biology of invasive alien plants in Canada 2. Cynanchum rossicum (Kleopow) Borhidi (=Vincetoxicum rossicum (Kleopow) Barbar.) and Cynanchum louseae (L.) Kartesz\&Gandhi (= Vincetoxicum nigrum (L.) Moench). Can J Plant Sci. 2004; 85(1): 243-263.

[8] Heywood VH, Brummitt RK, Culham A, Seberg O. Flowering Plant Families of the World. Firefly Books, Oxford University Press, New York, USA 2007.

[9] Liede S. Cynanchum-Rhodostegiella-Vincetoxicum-Tylophora (Asclepiadaceae): New considerations on an old problem. Taxon. 1996; 45(2): 193-211.

[10] Leimu R. Variation in the mating system of Vincetoxicum hirundinaria (Asclepiadaceae) in peripherial island populations. Ann Bot. 2004; 93(1): 107-113.

[11] Sliumpaite I, Murkovic M, Zeb A, Venskutonisa PR. Antioxidant properties and phenolic composition of swallowwort (Vincetoxicum lutea L.) leaves. Ind Crops Prod. 2013; 45: 74-82.

[12] Mansoor A, Ibrahim MA, Zaidi MA, Ahmed M. Antiprotozoal activities of Vincetoxicum stocksii and Carum copticum. Bangladesh J Pharmacol. 2011; 6(1): 51-54. 
[13] Lavault M, Richomme P, Bruneton J. Acetophenones and new pregnane glycosides from the roots of Vincetoxicum hirundinaria. Fitoterapia. 1999; 70(2): 216-220.

[14] Pavela R. Antifeedant activity of plant extracts on Leptinotarsa decemlineata Say. and Spodoptera littoralis Bois. larvae. Ind Crops Prod. 2010; 32(3): 213-219.

[15] Nowak R, Kisiel W. Hancokinol from Vincetoxicum officinale. Fitoterapia. 2000; 71(5): 584-586.

[16] Lavault M, Richomme P, Bruneton J. New phenanthroindolizidine N-oxides alkaloids isolated from Vincetoxicum hirundinaria Medic. Pharm Acta Helv. 1994; 68(4): 225-227.

[17] Coassini-Lokar L, Poldini L. Herbal remedies in the traditional medicine of the Venezia Giulia Region (North East Italy). J Ethnopharmacol. 1988; 22(3): 231-279.

[18] Baytop T. Türkiye'de Bitkiler ile Tedavi Geçmişte ve Bugün. İlaveli 2. Baskı, İstanbul Üniversitesi Eczacılık Fakültesi, Nobel Tıp Kitap Evleri, İstanbul, Türkiye 1984.

[19] Altundağ E, Öztürk M. Ethnomedicinal studies on the plant resources of east Anatolia, Turkey. Procedia Soc Behav Sci. 2011; 19: 756-777.

[20] Tuzlacı E, Doğan A. Turkish folk medicinal plants, IX: Ovacık (Tunceli). Marmara Pharm J. 2010; 3(14): $136-143$.

[21] Mogg C, Petit P, Cappuccino N, Durst T, McKague C, Foster M, Yack JE, Arnason JT, Smith ML. Test of the antibiotic properties of the invasive vine Vincetoxicum rossicum against bacteria, fungi and insects. Biochem Syst Ecol. 2008; 36(5-6): 383-391.

[22] Gibson DM, Krasnoff SB, Biazzo J, Milbrath L. Phytotoxicity of antofine from invasive Swallow-Worts. J Chem Ecol. 2011; 37(8): 871-879.

[23] Zaidi MA, Crow JSA. Biologically active traditional medicinal herbs from Balochistan, Pakistan. J Ethnopharmacol. 2005; 96(1-2): 331-334.

[24] Staerk D, Christensen J, Lemmich E, Duus J, Olsen CE, Jaroszewski JW. Cytotoxic activity of some phenanthroindolizidine N-Oxide alkaloids from Cynanchum vincetoxicum. J Nat Prod. 2000; 63(11): 1584-1586.

[25] Staerk D, Lykkeberg AL, Christensen J, Budnik BA, Abe F, Jaroszewski JW. In vitro cytotoxic activity of phenantroindolizidine alkaloids from Cynanchum vincetoxicum and Tylophora tanakae against drug-sensitive and multidrug-resistant cancer cells. J Nat Prod. 2002; 65(9): 1299-1302.

[26] Pavela R, Sajfrtova M, Sovova H, Barnet M, Karban J. The insecticidal activity of Tanacetum parthenium (L.) Schultz Bip. extracts obrained by supercritical fluid extraction and hydrodistillation. Ind Crops Prod. 2010; 31(3): 449-454.

[27] Güzel S, Pavela R, Kökdil G. Phytochemistry and antifeedant activity of root extracts from some Vincetoxicum taxa against Leptinotarsa decemlineata and Spodoptera littoralis. JBiopest. 2015; 8(2): 128-140.

[28] Güzel S, Pavela R, İlçim A, Kökdil G. Phytochemical composition and antifeedant activity of five Vincetoxicum taxa against Spodoptera littoralis and Leptinotarsa decemlineata. Marmara Pharm J. 2017; 21(4): 872-880.

[29] Stöckel K, Stöcklin W, Reichstein T. Die glucoside von Vincetoxicum hirundinaria MEDIKUS. 1. Mitteilung: Isolierung und Spaltprodukte. Glucoside und Aglucon. 316 Mitteilung. Helv Chim Acta. 1969; 52(5): 1175-1202.

[30] Tanker N, Koyuncu M, Coşkun M. Farmasotik Botanik, Ankara Universitesi Eczacılık Fakültesi, Ankara, Türkiye 2004.

[31] Browicz K. Vincetoxicum N.M. Wolf. In: Davis PH (Ed), Flora of Turkey and the East Aegean Islands. Edinburgh, 1978, 6. pp. 163-173.

[32] Güzel S, Pavela R, Kökdil G. Evaluation of antifungal effect of different polarity extracts from five Vincetoxicum taxa against Aspergillus fumigatus. International Anatolian Academic Online Journal/Health Science. 2015; 3(2): 1-9.

[33] Erşen D, Ülger M, Mangelinckx S, Gemili M, Şahin E, Nural Y. Synthesis and anti(myco)bacterial activity of novel 5,5-diphenylpyrrolidine $\mathrm{N}$-aroylthiourea derivatives and a functionalized hexahydro-1H-pyrrolo[1,2c]imidazole. Med Chem Res. 2017; 26(9): 2152-2160.

[34] NCCLS. Reference Method for Broth Dilution Antifungal Susceptibility Testing of Yeasts; Approved StandardSecond Edition. NCCLS document M27-A2 (ISBN 1-56238-469-4). NCCLS, 940 West Valley Road, Suite 1400, Wayne, Pennsylvania 19087-1898 USA 2002.

[35] Sönmez M, Çelebi M, Berber I. Synthesis, spectroscopic and biological studies on the new symmetric Schiff base derived from 2,6-diformyl-4-methylphenol with N-aminopyrimidine. Eur J Med Chem. 2010; 45(5): 1935-1940. 
[36] Güzeldemirci NU, Küçükbasmacı Ö. Synthesis and antimicrobial activity evaluation of new 1,2,4-triazoles and 1,3,4thiadiazoles bearing imidazo[2,1-b]thiazole moiety. Eur J Med Chem. 2010; 45(1): 63-68.

[37] Nateche F, Martin A, Baraka S, Palomino JC, Khaled S, Portaels F. Application of the resazurin microtitre assay for detection of multidrug resistance in Mycobacterium tuberculosis in Algiers. J Med Microbiol. 2006; 55: 857-860.

[38] Arif T, Mandal TK, Dabur R. 9. Natural products: Anti-fungal agents derived from plants. In: Mishra BB (Ed) Opportunity, Challenge and Scope of Natural Products in Medicinal Chemistry. Research Signpost, Kerala, 2011, pp. 283-311.

[39] Cowan MM. Plant products as antimicrobial agents. Clin Microbiol Rev. 1999; 12(4): 564-582.

[40] Bajpai VK. Antimicrobial bioactive compounds from marine algae: A mini review. Indian J Geomarine Sci. 2016; 45(9): 1076-1085.

[41] Kowalczyk D, Świeca M, Cichocka J, Gawlik-Dziki U. The phenolic content and antioxidant activity of the aqueous and hydroalcoholic extracts of hops and their pellets. J Inst Brew. 2013; 119(3): 103-110.

[42] Bazzaz F, Haririzadeh G. Screening of Iranian plants for antimicrobial activity. Pharm Biol. 2003; 41(8): 573-583.

[43] Pirbalouti AG, Jahanbazı P, Enteshari S, Malekpoor F, Hamedi B. Antimicrobial activity of some Iranian medicinal plants. Arch Biol Sci. 2010; 62(3): 633-642.

[44] Alimpić A, Knežević A, Milutinović M, Stević T, Šavikin K, Stajić M, Marković S, Marin P, Matevski V, DuletićLaušević S. Biological activities and chemical composition of Salvia amplexicaulis Lam. extracts. Ind Crops Prod. 2017; 105: 1-9.

[45] Lean SS, Yeo CC. Small, enigmatic plasmids of the nosocomial pathogen, Acinetobacter baumannii: good, bad, who knows? Front Microbiol. 2017; 8: 1547-1555.

[46] CLSI. Methods for Dilution Antimicrobial Susceptibility Tests for Bacteria That Grow Aerobically; Approved Standard-Ninth Edition. CLSI document M07-A9. Wayne, PA: Clinical and Laboratory Standards Institute 2012.

This is an open access article which is publicly available on our journal's website under Institutional Repository at http://dspace.marmara.edu.tr. 